\title{
microorganisms
}

ISSN 2076-2607

www.mdpi.com/journal/microorganisms

Review

\section{Biology of the Marine Heterotrophic Dinoflagellate Oxyrrhis marina: Current Status and Future Directions}

\author{
Zhiling Guo ${ }^{1,2,3}$, Huan Zhang ${ }^{3,4}$, Sheng Liu ${ }^{1}$ and Senjie Lin ${ }^{3,5, *}$
}

1 Key Laboratory of Tropical Marine Bio-resources and Ecology, South China Sea Institute of Oceanology, Chinese Academy of Science, Guangzhou 510301, China;

E-Mails: zhiling.guo@uconn.edu (Z.G); shliu@scsio.ac.cn (S.L)

2 University of Chinese Academy of Sciences, Beijing 100049, China

3 Department of Marine Sciences, University of Connecticut, Groton, CT 06340, USA;

E-Mail: huan.zhang@uconn.edu

4 Department of Environmental Science, Ocean University of China, Qingdao 266100, China

5 Marine Biodiversity and Global Change Research Center, Xiamen University, Xiamen 361005, China

* Author to whom correspondence should be addressed; E-Mail: senjie.lin@uconn.edu; Tel.: +1-860-405-9168; Fax: +1-860-405-9153.

Received: 2 July 2013; in revised form: 2 September 2013 / Accepted: 8 October 2013 / Published: 21 October 2013

\begin{abstract}
Heterotrophic dinoflagellates are prevalent protists in marine environments, which play an important role in the carbon cycling and energy flow in the marine planktonic community. Oxyrrhis marina (Dinophyceae), a widespread heterotrophic dinoflagellate, is a model species used for a broad range of ecological, biogeographic, and evolutionary studies. Despite the increasing research effort on this species, there lacks a synthesis of the existing data and a coherent picture of this organism. Here we reviewed the literature to provide an overview of what is known regarding the biology of $O$. marina, and identify areas where further studies are needed. As an early branch of the dinoflagellate lineage, O. marina shares similarity with typical dinoflagellates in permanent condensed chromosomes, less abundant nucleosome proteins compared to other eukaryotes, multiple gene copies, the occurrence of trans-splicing in nucleus-encoded mRNAs, highly fragmented mitochondrial genome, and disuse of ATG as a start codon for mitochondrial genes. On the other hand, O. marina also exhibits some distinct cytological features (e.g., different flagellar structure, absence of girdle and sulcus or pustules, use of intranuclear spindle in mitosis, presence of nuclear
\end{abstract}


plaque, and absence of birefringent periodic banded chromosomal structure) and genetic features (e.g., a single histone-like DNA-associated protein, cob-cox3 gene fusion, 5' oligo-U cap in the mitochondrial transcripts of protein-coding genes, the absence of mRNA editing, the presence of stop codon in the fused cob-cox3 mRNA produced by post-transcriptional oligoadenylation, and vestigial plastid genes). The best-studied biology of this dinoflagellate is probably the prey and predators types, which include a wide range of organisms. On the other hand, the abundance of this species in the natural waters and its controlling factors, genome organization and gene expression regulation that underlie the unusual cytological and ecological characteristics are among the areas that urgently need study.

Keywords: heterotrophic dinoflagellates; protist; Oxyrrhis marina; biology

\section{Introduction}

Heterotrophic protists are an essential link in the pelagic food webs, as consumers of primary production and prey to upper trophic levels, and can consume more than $60 \%$ of daily phytoplankton production from a broad range of oceanic and coastal systems [1-4]. Heterotrophic dinoflagellates are prevalent in the marine environments, with an abundance of up to $2 \times 10^{5}$ cells $\cdot \mathrm{L}^{-1}$ under non-bloom conditions [5,6]. They feed on a broad range of prey species, including phytoplankton, the eggs, early nauplii stages, and adult forms of some metazoans, ciliates, fish bloods and bacteria; at the same time they are important prey for many planktonic consumers, such as some metazoans, ciliates and other dinoflagellates $[7,8]$. Therefore, heterotrophic dinoflagellates play an important role in the carbon cycling and energy flow in the marine planktonic community [5].

Oxyrrhis marina is a widespread, free-living, and ecologically important heterotrophic dinoflagellate [9-11]. It is also an important model organism for a broad range of ecological [2,3,12-16], biogeographic [17-19], and evolutionary studies [3,10,20]. Despite the increasing number of studies on this organism, the existing data is scattered, remaining to be synthesized. Here we review the biology of this species in hope to provide a coherent picture on this organism and identify areas where further study is needed.

\section{Taxonomy and Phylogeny of Oxyrrhis}

Early morphological studies have raised disputes over whether the genus of Oxyrrhis contains multiple species (O. marina, O. maritima van Meel 1969, O. phaeocysticola Scherffel 1900 and O. tentaculifera Conrad 1939) or only one species (O. marina) [10,21-25]; however, recent molecular phylogenetic studies favor the notion that two sibling species exist in this genus. Cavalier-Smith and Chao [26] suggested that Oxyrrhis consists of at least two species based on sequence variations in the small subunit ribosomal RNA gene (SSU rDNA). Lowe et al. [27] conducted the phylogenetic analysis of 5.8S rDNA-internal transcribed spacer (5.8S rDNA-ITS) and mitochondrial cytochrome c oxidase I gene (cox1) sequences, and found two highly divergent lineages within O. marina morphospecies, thus proposing the existence of two Oxyrrhis species: O. marina and O. maritima. A recent phylogenetic 
analysis of three genes (cox1, $\alpha$-tubulin, 5.8S rDNA-ITS) for 350 water samples from 149 locations throughout Europe also showed two distinct O. marina lineages [4]. Since Oxyrrhis spp. are ubiquitous in the coastal waters and are easy to be isolated, to date, nearly 400 different $O$. marina-like isolates have been reported in the literature $[4,18,28,29]$; for accurate species identification of the isolates, it is important to use both morphological and molecular methods. For convenience, in this review, we will refer to this species complex as O. marina.

The phylogenetic position of $O$. marina is controversial. Some of the morphological and cytological studies support its basal position in the dinoflagellate lineage [20,30,31], while others infer a highly derived position within the order of Gonyaulacales [24,26,32]. However, with a growing wealth of molecular data on dinoflagellates, such as the phylogenies based on various genes, mitochondrial genome structure, RNA editing, and trans-splicing of nucleus-encoded mRNA [32-36], the majority of recent studies supports $O$. marina as an ancestral dinoflagellate lineage.

\section{Unusual Cytological and Genetic Features}

O. marina displays many characteristics that differ from those of typical dinoflagellates. These features make this species cytologically and genetically closer to a typical eukaryote than a typical dinoflagellate.

\subsection{Morphology}

The structure and function of the flagellar apparatus in O. marina are different from those in other dinoflagellates. The majority of dinoflagellates either have a longitudinal and a transverse flagellum, emerging from the sulcus and the cingulum, respectively, or both flagella growing from the apical area (Prorocentrales). In contrast, O. marina's both flagella grow from the ventral side. Furthermore, the flagella in $O$. marina possess a row of complex mastigonemes while lack a broad striated strand on the transverse flagellum, and both transverse and longitudinal flagella are covered with scales [37-39]. In addition, the structure of $O$. marina flagellar root system is also significantly different from that of other dinoflagellates, including the breadth of the posteriorly directed microtubular root, the orientation of connective structures and electron dense core of the ventral microtubular root, and the existence of fibers that parallel the flagella [10,40,41].

\subsection{Nuclear, Mitochondrial and Plastid Genomes}

O. marina shares a few common characteristics with other dinoflagellates as concerns nuclear and organellar genomes. Its nuclear chromosomes remain condensed throughout the cellular cycle [18]; the proteins which constitute the structural basis of the nucleosomes are less abundant than in typical eukaryotic chromatin [42]; trans-splicing occurs in nucleus-encoded mRNAs [43,44]; its mitochondrial genome appears to be highly fragmented and mitochondrial genes use non-canonical start codons [34].

O. marina also exhibits unique nuclear and chromosomal organization which distinguishes it from typical dinokaryotic dinoflagellates [45]. Mitotic cell division of $O$. marina is facilitated by an intranuclear spindle rather than an extranuclear spindle observed in typical dinoflagellates [46,47]. In O. marina, nuclear plaque from which the spindle is generated develops in the nuclear envelope at 
prophase, but this structure does not appear in the typical dinoflagellates. During division, the nuclear envelope in typical dinoflagellates invaginates to form cytoplasmic channels where the microtubules are present, while in O. marina, the nuclear envelope does not invaginate and the microtubular mitotic apparatus is intranuclear [31,47]. The birefringent periodic banded or arched chromosomal structure, which is typical in dinoflagellates, has not been observed in O. marina. While chromosomes divide in the mitosis phase in typical eukaryotes, there is some evidence, which suggests that chromosome division in O. marina may occur throughout most of the cell cycle [47-49]. The movement of the chromosomes in $O$. marina is driven by microtubules directly, while in typical dinoflagellates it is driven by microtubules through the nuclear envelope [46,47]. Other differences between Oxyrrhis and the typical dinoflagellates include the presence of a large number of long, thin chromosomes that are separated by many electron-dense bodies, the possession of a single histone-like DNA-associated protein, and the absence of a girdle, a sulcus or pustules in Oxyrrhis [32].

While dinoflagellates are generally considered to be haploid [50,51], the true ploidy of $O$. marina is uncertain [52]. The genome size of a typical dinoflagellate ranges from $\sim 1.5$ to over $250 \mathrm{pg} \cdot \mathrm{cell}^{-1}$,

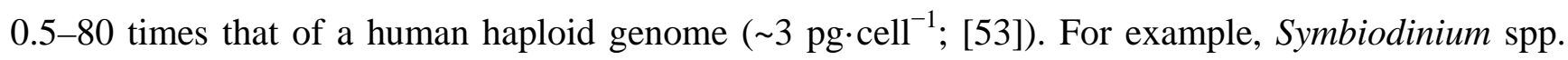
possess relatively small genomes (1.5-4.8 $\left.\mathrm{pg} \cdot \mathrm{cell}^{-1}\right)$, while Prorocentrum micans has a much larger genome, estimated to be $230-280 \mathrm{pg} \cdot \mathrm{cell}^{-1}[54,55]$. There is only one report on $O$. marina genome size, with an estimate of $55.8 \mathrm{pg} \mathrm{cell}^{-1}$ [48]. This estimate is not consistent with the fact that $O$. marina is cytologically more similar to typical eukaryotes, and therefore remains to be further verified.

To date (June 2013), there are about 19 thousand Oxyrrhis nucleotide sequences reported in GenBank databases, most of them are unannotated expression sequence tags (EST); the annotated gene sequence information is mostly restricted to a few genes [e.g., rDNAs, ITS, actin, cox1, cytochrome $b$ (cob), rhodopsin, heat shock protein ( $h s p$ ) 90, $\alpha$ - and $\beta$-tubulin]. In dinoflagellate genomes, many genes occur in multiple copies (e.g., peridinin-chlorophyll $\alpha$-binding protein gene ( $p c p)$ in Gonyaulax polyedra by Le et al., 1997 and Symbiodinium sp. by Reichman et al., 2003; actin in Amphidinium carterae by Bachvaroff and Place, 2008; 18S rDNA in Am. carterae, Alexandrium taylori and Pr. minimum by Galluzzi et al., 2010, Al. fundyense by Erdner et al., 2010 [56-60]); some genes have been reported to occur in multiple copies in O. marina (e.g., actin, $\alpha$-tubulin, hsp90, hsp70 and Adenosylhomocysteinase gene) [49]. The copy number of actin, $\alpha$-tubulin and $h s p 90$ in the O. marina genome was estimated to be 33, 10, 5, respectively [48]. Most of the dinoflagellates genes studied so far are arranged in tandem repeats (e.g., $p c p$ in G. polyedra; luciferase genes (lcf) in Lingulodinium polyedrum; form II ribulose-1,5-bisphosphate carboxylase gene ( $r b c I I)$ in Pr. minimum; proliferating cell nuclear antigen gene (pcna) in Pfiesteria piscicida; actin in Am. Carterae) [56,58,61-64] although whether they are transcribed as polycistronic transcripts may vary with species and genes (e.g., [61,63,65]). Even in Perkinsus marinus, a close alveolate relative of dinoflagellates, some genes such as cyclin2 occur in tandem repeats [64].

While whole genome sequencing for any dinoflagellate is still impractical due to the excessively large genome size, next generation sequencing can provide efficient strategy to generate functional genomic level data. Recently, O. marina cultured under different salinity conditions was subjected to transcriptomic analysis using 454 pyrosequencing technology, and about 7000 contigs were retrieved. Bioinformatics analysis of these contigs indicated that some genes occurred as tandem repeats (e.g., $\alpha$ - and $\beta$-tubulin, elongation factor 2 gene, rhodopsin, $h s p 90$ ), and multiple transcribed gene variants 
were common, suggesting a potentially complex genomic arrangements in this organism [66]. In dinoflagellates, some genes are thought to be acquired via lateral (horizontal) gene transfer (LGT) from prokaryotes, e.g., shikimate biosynthesis gene ( $\operatorname{aroB}$ ) and $O$-methyltransferase gene (omt) from cyanobacteria [67], and $r b c I I$ from an $\alpha$-proteobacteria [68,69]. Although LGT has not been examined in detail in O. marina, it has been reported that $O$. marina may have gained genes through LGT via feeding, because the frequent and intimate interaction with prey organisms increase the likelihood of gene transfer [49].

Alveolata, which comprises ciliates, dinoflagellates and apicomplexans [32], has a potentially informative history of mitochondrial genome evolution. Of these lineages, ciliates are thought to branch first from their common ancestor and contain conventional mitochondrial genomes (or mtDNA) [70,71]. For example, ciliates mtDNA is fairly large, and contains 43-52 protein coding genes; its small (SSU) and large (LSU) subunit rRNAs are split into two transcription units. Compared to the large and gene-rich mtDNA in ciliates, the mtDNA of apicomplexans is simple and highly reduced, containing only three protein-coding genes [cob, cox1 and cytochrome oxidase III (cox3)] and highly fragmented rRNAs, indicating a considerable mitochondrial gene loss or relocation to the nucleus during alveolate evolution [71]. Despite being sister lineage to apicomplexans and the persistence of some intriguing similarities (e.g., absence of tRNA genes; highly fragmented SSU and LSU rRNAs with similarity in length and sequence termini; the existence of polycistronic transcripts; high level of gene relocation from the mitochondrion; three protein-coding genes), the mtDNA arrangement in dinoflagellates is radically different from that in the apicomplexans, including its complex mitochondrial genome, multiple gene copies in different genomic contexts, RNA editing of protein-coding and rRNA transcripts, non-streamlined mtDNA, loss of stop codons from protein-coding genes, and dispersion of mitochondrial genes over several hundred linear chromosomes [34,71].

As an early branch of the dinoflagellate lineage, $O$. marina exhibits some notable exceptions in mitochondrial genome features. O. marina mtDNA contains the smallest gene complement known to date, with only two protein coding genes and several rRNA fragments [34]. While in most of the dinoflagellate mitochondrial genomes studied so far, cob, cox1 and cox3 are encoded separately; in O. marina mitochondria, $c o b$ and cox3 are fused to form a single coding unit, and mRNAs are oligo (U) capped at the $5^{\prime}$ end $[34,49]$. In typical dinoflagellates, no stop codon has been found in $c o b$, cox1 and cox3 transcripts, indicating a different translation termination mechanism from other eukaryotes [70-73]. In O. marina, although stop codons are absent in cox1 transcripts, the fused cob-cox3 mRNA seems to have a stop codon that is produced through post-transcriptional oligoadenylation [34]. A similar oligoadenylation mechanism of cox3 mRNA has also been observed in two other relatively deep-branching dinoflagellates Am. carterae and Karlodinium veneficum [71]. O. marina mitochondrial genome appears to be duplicated and recombined, as is in other dinoflagellates such as Am. carterae, Crypthecodinium cohnii, K. veneficum, and Hematodinium sp. In addition, mRNA editing of mitochondrial genes, which is common in dinoflagellates, is not found in O. marina [34,36,74]. This, and similar absence of mRNA editing of mitochondrial genes in other apparently basal dinoflagellate lineages and Apicomplexa have led us to postulate that mitochondrial mRNA editing arose later in dinoflagellate evolution [75]. However, a recent study detected mitochondrial mRNA editing in the parasitic and more basal dinoflagellate Hematodinium sp. (in the order of Syndiniales), extending the emergence of mRNA editing to an earlier stage of the dinoflagellate evolution [76], 
suggesting a possibility that this feature occurred in the common ancestor of dinoflagellates and was subsequently lost in O. marina and other basal dinoflagellate lineages.

In non-photosynthetic organisms, photosynthesis-related genes are usually lost or have become pseudogenes [74]. In O. marina, however, a number of genes encoding proteins associated with the plastid or photosynthesis have been identified (e.g., ketol-acid reductoisomerase, carbonic anhydrase, cysteine synthase, 1-deoxy-D-xylulose-5-phosphate reductoisomerase, haem, ascorbate peroxidase, glutamine synthetase, hydroxymethy lbilane synthetase, ribulose 5-P isomerase, and dihydrodipicolinate reductase) [9,66]. Moreover, plastid-targeting peptides have been detected in some proteins of this species. All these suggest that $O$. marina may have evolved from a plastid-bearing ancestor and a cryptic plastid may still exist in O. marina to fulfill some metabolic pathways [9]. Vestigial plastid genes have also been found in some parasitic and heterotrophic alveolates such as the Apicomplexa [77-79], ciliates [80,81], and Perkinsus [82,83]. It is reported that the relict plastid can support essential metabolic functions in Apicomplexa, including haem biosynthesis, type II fatty acids synthesis, and isoprenoid precursor biosynthesis, which play an important role for parasite survival in different host settings [84]. These results are consistent with the suggestion that chromavelolates share a common photosynthetic ancestor [85-87]. Photosynthesis-related gene rbcII has been found in the non-photosynthetic dinoflagellate C. cohnii [74]; whether this gene is present in O. marina is unclear but would be worth investigating as it can provide valuable insights into the evolution of rbcII in dinoflagellates.

\section{Nutritional Modes}

O. marina represents an intriguing mix of feeding strategies compared with most heterotrophic protists. This includes phagotrophy, saprotrophy, cannibalism, and phototrophy (harvesting solar energy to enhance growth).

\subsection{Phagotrophy}

O. marina can feed by phagotrophy on a variety of prey belonging to diverse taxa and size categories, including phytoplankton, the eggs and nauplii of metazoa, ciliates and bacteria (Figure 1; [9]). The typical cell size of $O$. marina is 20-30 $\mu \mathrm{m}$ [18]. Its optimum prey size is smaller than its own size, and it grows at high rates when feeding on small flagellates (siz屯 $\mu \mathrm{m}$ ) [88-91]. It ingests prey by engulfment, which appears to be more efficient than other feeding mechanisms [5]. Maximum ingestion and clearance rates of $O$. marina on phytoplankton range from 0.07 to $2.8 \mathrm{ng} \mathrm{C}_{\text {day }}{ }^{-1}$ per grazer and 0.002-0.015 $\mu \mathrm{L}$ per grazer $\cdot \mathrm{h}^{-1}$, respectively [2,5,88]. Jeong et al. [8] reported that bacteria alone could support the growth of $O$. marina, and that the ingestion and clearance rates on bacteria could be up to 71.3 and 31.3 cells $\cdot h^{-1}$, respectively, much higher than those of other heterotrophic dinoflagellates.

The maximum growth rate of $O$. marina is relatively high, $\sim 0.033 \mathrm{~h}^{-1}$ when fed with Dunaliella tertiolecta or Isochrysis galbana, and $0.054 \mathrm{~h}^{-1}$ with Phaeodactylum tricornutum [5,88]. Although O. marina demonstrates remarkable versatility in its prey, it has feeding preferences. When fed with artificial particle prey, O. marina exhibits selective feeding based on the size, biochemical composition and charge of the particles. For example, O. marina prefers $4 \mu \mathrm{m}$ over $1 \mu \mathrm{m}$ beads, and beads coated with mannose-BSA over $N$-acetylgalactosamine-BSA [92-94]. 
Even though O. marina can ingest artificial particles, it prefers live prey and can discriminate between different species. It has been reported that $O$. marina can use the mannose-binding lectin on the cell membrane to distinguish different prey species [94]. A number of studies have investigated the prey selectivity of $O$. marina, yet because they used different initial ratios of prey and predator, biomasses and biovolumes, incubation conditions and durations, their conclusions were different [88,89,95-97]. In addition, many traits of prey, such as cell size and shape, motility, hydrophobicity, nutritional value, dissolved chemical cues, and cell surface properties, can vary between different prey species. Therefore, it is difficult to determine the factors that influence the prey selectivity between species [5,98-102]. $O$. marina can also discriminate individuals of the same species with different properties. For example, it grazes selectively on virus-infected over healthy Emiliania huxleyi, and low dimethylsulphoniopropionate (DMSP) lyase-activity strains over high DMSP lyase-activity strains [103,104].

\subsection{Saprotrophy}

In addition to phagotrophy, O. marina can survive through the uptake of dissolved organic molecules, indicating its capability to feed by saprotrophy. When cultured in $f / 2$ medium supplied with ethanol or acetate as carbon source but free of complex nutrients, O. marina still grew successfully [105]. It has been reported that $O$. marina is able to synthesize the full complement of amino-acids by using ammonium or other nitrogen sources as substrate [106,107]. Slamovits and Keeling [9] reported that O. marina has Ketol-acid reductoisomerase, which is involved in the synthesis of the essential amino acids Valine, Leucine and Isoleucine. By analyzing a 454-based transcriptome dataset obtained from O. marina, Lowe et al. [66] identified a broad range of genes associated with amino acid synthesis and metabolism, indicating the biosynthetic capacities of this species.

\subsection{Cannibalization}

O. marina is known to be cannibalistic in a food-deficient environment, but usually only a small proportion ( 2\%) is cannibals in a population. Öpik and Flynn [108] found ingested Oxyrrhis cells in O. marina by electron microscopic observation. Factors that drive feeding on conspecific cells are not well understood, but cannibalism may help the population to survive when their usual prey is scarce $[3,5]$.

\subsection{Phototaxis, Circadian Rhythm, and the Potential of Solar Energy Utilization}

As in other unicellular organisms, photosensory capability exists in many heterotrophic protists [109-115]. Hartz et al. [19] observed that O. marina exhibited positive phototaxis to different wavelengths of light, suggesting its ability to use photosensory response to orient in their environment and locate prey.

O. marina seems to possess an endogenous circadian clock that controls its feeding and growth. Jakobsen and Strom [116] examined the responses of feeding (and growth) rates in O. marina to both the light: dark cycle and continuous darkness treatments, and found that $O$. marina fed and divided with a diel rhythm, with higher feeding and growth rates during the light period, and the persistence of diel differences in feeding and growth during 24-h exposure to continuous darkness. These results 
demonstrated that the circadian rhythm was controlled by biochemical processes endogenously generated. They also observed that $O$. marina lost its diel cycle when removing the external modulating light cue for $230 \mathrm{~h}$, indicating that the circadian rhythm was cued by a light-modulated signal, and the irradiance threshold for maintenance of the circadian cycle was $3.1 \times 10^{-4} \mu \mathrm{mol}$ photons $\mathrm{m}^{-2} \cdot \mathrm{s}^{-1}$.

O. marina exhibits some phototrophic capabilities. It has been reported that light may stimulate grazing and enhance population growth of mixotrophic and heterotrophic protists [117-120]. The light-dependent benefit may come from phototaxis, as observed in O. marina, which may motivate the prey searching activity $[2,116]$, but it may also come from photodegradation of ingested food and stimulation of digestive enzymes as postulated for other protists [117,121]. It has been observed that growth and feeding rates of $O$. marina is higher in the light than in the dark [2,116]. Klein et al. [122] found that light promoted alloxanthin and chlorophyll c degradation by O. marina. Besides, Lin and colleagues found that $O$. marina and other dinoflagellates possessed and expressed a proton-pump type rhodopsin, which was highly similar to proteorhodopsin previously found in a wide range of proteobacteria living in the ocean surface [42,123-125]. Whether dinoflagellate rhodopsin has been acquired through horizontal gene transfer from marine bacteria remains to be further studied.

Although the function of $O$. marina rhodopsin is still unclear, it is suspected that this type of rhodopsin may generate energy from light directly to power biological functions, or acidify digestive vacuoles using light rather than ATP [126]. Furthermore, by sequencing about 18,000 EST from O. marina, Slamovits et al. [126] found that there were two different types of rhodopsin, and proposed that one of them was sensory rhodopsin. Different types of rhodopsin may express differentially and play different physiological roles.

\section{Swimming and Feeding Behaviors}

\subsection{Swimming Behavior}

Early studies showed that the two morphologically and functionally differentiated flagella were responsible for the swimming motion of $O$. marina $[127,128]$. One of the flagella is the extending longitudinal flagellum which produces the planar and symmetrical waves to push the cell forward; the other is the coiled transverse flagellum which partially wraps around the cell from its origin in a ventral furrow and produces the helical waves to propel the cell forward $[39,127,128]$. The beating of these two flagella causes $O$. marina to swim in three-dimensional helical path, generally with a 44-80 $\mu \mathrm{m}$ helical width, and a mean forward displacement of $400-700 \mu \mathrm{m} \cdot \mathrm{s}^{-1}$ for completing a full helical rotation [129]. The helical swimming-related parameters, including the swimming speed, rotational movement, helical extent and directional persistence, can be affected by environmental stimuli (e.g., food items and chemical cues) [16,130]. Since the volume of water sampled across the net direction of movement is wider and the searching radius is increased when swimming in a helix, the foraging efficiency of this organism is higher [131]. O. marina also exhibits a run-and-tumble swimming behavior, where it reorients itself by folding the longitudinal flagellum after periods of long-straight movements [16,129].

Swimming behavior is associated with the abundance of the prey. It has been recorded that more frequent turning, shorter runs and higher swimming speed occur in the presence of food than when 
without food [132-134]. Swimming behavior of O. marina also varies with different prey concentrations, and these changes are physically controlled by the flagellar movement, involving more energy in using longitudinal flagellum at high prey concentration $\left(\sim 10^{4}-10^{5}\right.$ cells $\left.\cdot \mathrm{mL}^{-1}\right)$ and performing frequent transverse flagellum movement at low prey concentrations $\left(\sim 10^{1}-10^{3}\right.$ cells $\left.\cdot \mathrm{mL}^{-1}\right)$ [2]. O. marina is capable of directed swimming which contributes to exploiting patchily distributed resources [16,134]. Swimming speed, changes in the direction, and frequency of turning will subsequently influence spatial distribution and the prey searching of O. marina [2]. For example, in the presence of food, higher swimming speed and turning angles result in a decrease in the diffusivity of O. marina [134].

\subsection{Feeding Behavior}

O. marina feeding includes several stages: prey searching, contacting and capturing, processing, ingesting and digesting [2]. Prey searching is triggered by the environmental stimulus and usually is a process of the recognition and detection of the dissolved chemoattractants by the predator. Generally $O$. marina exhibits a positive motile response in the presence of various chemical cues, including prey cells, prey exudates and infochemicals; this response involves cell signal transduction process which is initiated by the binding of a chemical molecule released by prey to a specific cell surface receptor of O. marina [2,134]. It has been reported that G-proteins, G-proteins-coupled receptors, and protein kinases may be involved in the signaling pathways initiating motile behavior [135].

The detailed mechanisms underlying contacting, capturing, and processing prey in this organism are still poorly understood, because its swift movement and rapid engulfment of prey make it challenging to observe accurately. Fenchel [136] reported that O. marina exhibited two different feeding behaviors: raptorial feeding and filter feeding, depending on the size of prey. Jeong et al. [8] investigated the feeding behavior of $O$. marina on marine bacteria, and found that the bacteria were trapped in the feeding currents produced by the transverse flagellum of $O$. marina and were moved toward the cingular depression, where the bacteria were engulfed, indicating that this species is an intercept feeder of bacteria. O. marina shows more active and vigorous performance when the prey is a protist. It has been reported that within 15 min of addition of Dunaliella, up to three prey cells could be seen inside individual Oxyrrhis, with 10 and 15-20 prey cells by 3 h and 9 h, respectively [108]. Therefore, O. marina may be advantaged in gaining energy by using different feeding behaviors (raptorial, filter and interception feeding).

There are contradictions regarding the time of contact of prey and predator and the involvement of trichocysts in prey capture. For example, the contact of prey and predator was noted to occur prior to [137] or following $[8,138]$ the encircling of prey by O. marina. In some cases the trichocysts and filaments were observed to involve in the prey capture activity $[8,108]$; however, studies by Höhfeld and Melkonian [137] suggested the absence of trichocysts during the stages of phagocytosis.

The prey processing is a stage during which $O$. marina may select the prey and decide whether or not to accept certain food types [101,139]. Following this is the ingestion phase by phagocytosis, which involves the rearrangement of the microtubular cytoskeleton. During this stage, prey is firstly adhered to the predator through the binding of receptors on predator to ligands on the cell surface of prey, and then ingested by phagocytosis in a temporary cytostome through protein kinase-based signaling 
pathways [2,135]. After the prey is engulfed, the cells firstly become more electron-dense and the contents coagulated, and later less distinct and disintegrated to granular-membranous masses, and finally only the vesicular deposits are identifiable and the prey is completely digested [108].

Figure 1. The schematic showing relationships of $O$. marina with other organisms as prey and predators as documented in literature. The black-colored arrows emerging from the variety of prey all point to O. marina as the grazer, while the red-colored arrow emerging from $O$. marina leads to the diverse predators of $O$. marina.

\begin{tabular}{|l|l|}
\hline Dinoflagellates \\
Amphidinium carterae \\
Heterocapsa rotundata \\
Karlodinium veneficum \\
Luciella masanensis \\
Oxyrrhis marina \\
Pfiesteria piscicida \\
Prorocentrum minimum \\
P. micans \\
Stoeckeria algicida
\end{tabular}

Being an important predator on the one hand, O. marina is a suitable food source and an appropriate prey size for a range of organisms on the other hand. O. marina predators include fish larvae, copepods (Acartia clause, Temora longicornis and Centropages hamatus), ciliates, and rotifers (Figure 1; [3,140,141]). For examples, O. marina fed with Dunaliella sp. synthesizes long-chain fatty acids and sterols; using this $O$. marina culture as food for copepods results in higher growth rate than copepods only supplied with Dunaliella [142]. O. marina can provide rotifer predators with tryptophan that is not abundant in the algal prey [143]. There is report that $O$. marina sometimes could become food of its prey when the nutrient is stressed. For example, mixotrophic haptophyte Prymnesium parvum is a suitable prey for $O$. marina under normal conditions, but when exposed to nutrient-stressed $P$. parvum cultures, which produce toxin, O. marina loses its motility, lyses and finally is consumed by P. parvum [12,13]. 


\section{Life Cycle and Cell Cycle}

\subsection{Life Cycle}

Most of the dinoflagellates have a haplontic life cycle [50,51]. The life cycle of dinoflagellates is influenced by the ambient environmental conditions. Under favored conditions, cells divide and the population grows by binary fission, while in stressed conditions, cells act as gametes and fuse into a diploid zygote which then undergoes a meiotic division to produce new haploid cells [144]. So far, little is known about the life cycle of $O$. marina. It is believed that $O$. marina is isogamous; gametic cells are formed by two typical meiotic divisions and consequently are much smaller than vegetative cells [18]. Montagnes et al. [18] observed small $O$. marina cells $(\sim 8 \mu \mathrm{m})$ from all of the $\sim 400$ isolates of $O$. marina cultures, and proposed that they might be gametes; however, there was no evidence of fusion of these mini-cells.

\subsection{Cell Cycle}

In O. marina, cell division is by transverse fission. As in other dinoflagellates, the chromosomes are always condensed during the cell cycle, but the structural organization of division is different from other dinoflagellates [18]. Similar to the typical eukaryotes, the cell cycle of the exponentially growing O. marina cells contains four phases: $\mathrm{G}_{1}, \mathrm{~S}, \mathrm{G}_{2}$, and $\mathrm{M}$, with the major portion (50\%) being in $\mathrm{G}_{2}$ and $\mathrm{M}$ phases $[48,145]$, the two phases that are indistinguishable by flow cytometry, the method commonly used to analyze the cell cycle. Cells in stationary phase usually accumulate in $G_{1}$ and $G_{2}$, and nutrient-stressed cells accumulate at $\mathrm{G}_{2}$ to allow rapid exploitation of new resources once the nutrients are replete [145], suggesting the nutrient-dependent cell cycle control points are located in both of these phases to allow $O$. marina to adapt to the feast-or-famine conditions. $P$. piscicida, another heterogrophic dinoflagellate, also tends to accumulate in G2 when prey is depleted, apparently to allow rapid population recovery by entering cell division once prey is resupplied [146].

\section{Physiology}

A well-fed, dense $O$. marina culture has pinkish color $[20,147]$. We observed the same phenomenon, but usually after prey have been consumed, suggesting induction of rhodopsin as a result of accelerated food digestion or food depletion. The cell size and shape are highly variable in O. marina due to different osmotic conditions, temperature, food concentrations and culture status, and can also be clone-specific [10,148]. Jonsson [149] found that in intertidal rock pools Oxyrrhis sp. formed robust adherent cysts associated with the tidal cycle. Recently Montagnes et al. [18] also found thin-membrane covered cysts in $O$. marina cultures. Resting cysts have also been described in other dinoflagellates, with functions ranging from survival during adverse conditions, bloom initiation and termination, and a seed bank for genetic diversity and wide dispersal [150-153].

The growth rate of $O$. marina is affected by various abiotic factors, including salinity $[17,154]$, turbulence [155], temperature [148], $\mathrm{pH}$ [156] and tidal cycle and height [149]. O. marina can grow at 0.67 and 0.34 day $^{-1}$, respectively, when cultured in 30 and 50 practical salinity unit (PSU) Droop's S69 axenic growth medium [66]. High turbulence has negative effect on O. marina growth, 
which can decrease growth rate by $20 \%$ [155], while low-level turbulence can increase the encounter with prey, and hence increase the growth [157]. Jonsson [149] investigated the relationship between $O$. marina abundance and tidal action, and identified a positive correlation between tidal height and abundance of $O$. marina on the Isle of Man. O. marina exhibits strain-specific differences of physiological responses to a diversity of environmental factors [158].

\section{Geographic Distribution}

Firstly isolated from a salt marsh in Belgium over 150 years ago, O. marina is commonly found in shallow waters and littoral and supralittoral pools, but rarely found in the open oceans [3,11,143,148,159]. It is globally distributed in coastal and intertidal waters, having been reported in the Atlantic and Pacific coasts of the USA, the Gulf of Mexico, the Atlantic coasts of Europe, the Mediterranean sea, the Persian Gulf, the Indian Ocean and the western Pacific [11], the Gulf of Finland and the south and west Baltic and Red Seas [160], the White Seas [24], intertidal pools on the Isle of Man [159], the Amursky Bay in Japan [147,161], the Southern Bay of Biscay [162], and the Chesapeake Bay [163]. Undoubtedly, the wide distribution of $O$. marina is associated with its eurytopic characteristics and its ability to tolerate varying environmental conditions.

Lowe et al. [27] conducted phylogeographic analyses using cox1 and 5.8S rDNA-ITS on 58 Oxyrrhis isolates from a range of locations and reported that $O$. marina showed high genetic diversity and broad-scale spatial structure. Two highly divergent lineages existed within $O$. marina morphospecies, with each composed of two distinct clades, with clades 1 and 2 (lineage 1) more abundant and widespread, and clades 3 and 4 (lineage 2) rare and spatially restricted [27]. Furthermore, using highly polymorphic microsatellites markers, Lowe and colleagues found that $O$. marina had high genetic diversity even on small spatial scales [28]. The high genetic diversity may reflect adaptive variation in this species. It is reported that $O$. marina can tolerate a wide range of temperature $\left(8-30{ }^{\circ} \mathrm{C}\right)$, salinity (4-130 PSU), and pH (7.8-9.8) [11,18,65].

Although there are extensive reports on the geographic distribution of $O$. marina, information on its abundance is rare. O. marina was observed to form a bloom in Amursky Bay, in the coastal water of the Northern Sea of Japan in July 2002, with the maximum cell concentration of $4.4 \times 10^{5}$ cells $\mathrm{mL}^{-1}$ [147]. Johnson et al. [163] noted the abundance of $O$. marina at about $0-100$ cells $\cdot \mathrm{mL}^{-1}$ in summer in Chesapeake Bay, MD, USA. All the quantitative data of $O$. marina abundance currently available were based on microscopic identification, which is time-consuming and technically challenging because the samples may have distorted cell morphology, making $O$. marina species identification difficult microscopically [164-166]. Over the past decades, several taxon-specific molecular detection approaches based on signature of genetic variability have been developed, among which real-time quantitative PCR (qPCR) has been successfully used to quantify many dinoflagellate species including Al. fundyense [167], Al. minutum [166], Al. tamarense [168] (likely Al. fundyense sensu Wang et al. 2013 [169]), Al. catenella and Al. taylori [59], Karenia mikimotoi [170], K. veneficum [171], Pf. piscicida [172], Pf. shumwayae [165], and Symbiodinium sp. [173]. Therefore, molecular techniques such as qPCR are needed for rapid detection and quantification of O. marina from environmental samples in the future, and information on O. marina abundance in the marine ecosystem is needed to better understand the seasonal- and long-term population dynamics and thus ecological roles of this 
species. Furthermore, the mechanisms that sustain the high levels of genetic diversity in this organism need to be uncovered.

\section{Future Directions for Research on O. marina}

As a phylogenetically basal lineage and a widely distributed species of the heterotrophic dinoflagellates, O. marina represents an excellent model for evolutionary and ecological studies of dinoflagellates. Despite the increasing attention paid to this species, there are still many unanswered questions (Figure 2). For example, what is the abundance of O. marina in the natural environment? How are the different genotypes distributed geographically? What are the evolutionary force to create and ecological mechanisms to sustain the high levels of genetic diversity in this organism in the natural marine environments? Does the wide range of prey species O. marina is able to consume in the laboratory reflect a broad prey spectrum of this species in the natural environments and does this flexibility "buffer/dampen" predator-prey cycles? What is the genome size of this organism and how is the genome organized? Does rhodopsin-related energy-producing pathway exist in $O$. marina, and if so, to what extent may this energy acquisition contribute to this organism's growth? Based on these questions, below we will propose some ideas for future studies.

Figure 2. Diagram summarizing the current status of knowledge in key areas and showing proposed future research topics to address the inadequacy of those areas.

Current Knowledge
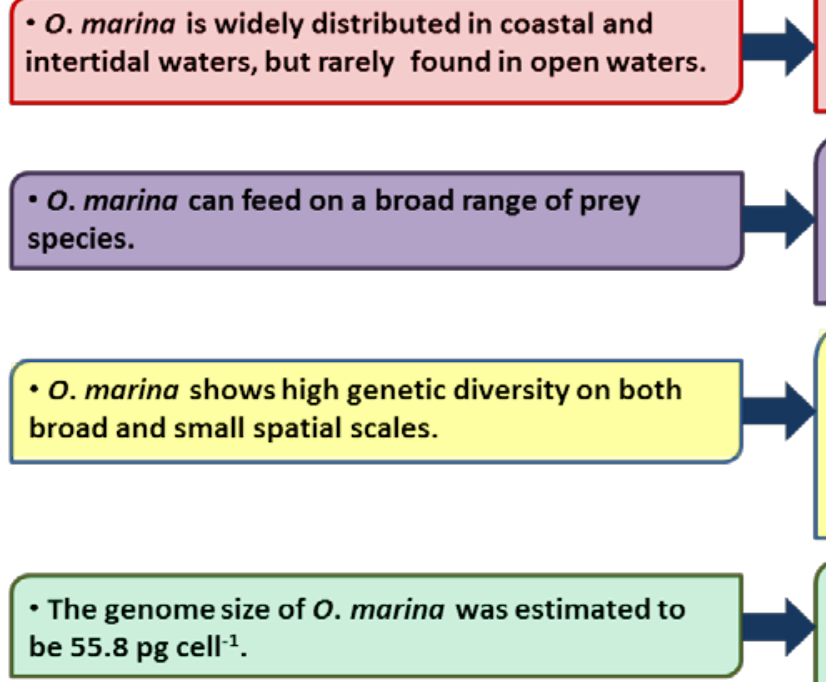

O. marina exhibits positive phototaxis to different
wavelengths of light.
- O. marina possesses and expresses a proton-pump
type rhodopsin.

Future works

1) What is the abundance of $O$. marina in the natural environment?

2) Why is it rare in open waters?

1) What is the contribution of $O$. marina to the carbon cycling and energy flow in the marine planktonic food webs? 2) What drives the prey selectivity? What are the mechanisms underlying feeding behavior?

1) How are the different genotypes distributed geographically?

2) What are the evolutionary force to create and ecological mechanisms to sustain the high levels of genetic diversity in this organism in the natural marine environment?

1) What is the true genome size of this organism? Does it vary between genotypes?

2) How is the genome organized?

1) Does rhodopsin-related energy-producing pathway exist in $O$. marina?

2) To what extent may this energy acquisition contribute to this organism's growth?

\subsection{O. marina Abundance in the Natural Environment}

Quantifying the abundance of $O$. marina in the natural environment may gain insights into the seasonal- and long-term population dynamics and thus ecological roles of this species. O. marina is a non-thecate dinoflagellate; samples preserved may have distorted cell morphology, making $O$. marina 
species identification difficult under the microscope. Molecular techniques, especially qPCR methods are needed to quantify the abundance of $O$. marina. The accuracy of the qPCR technique to quantify phytoplankton in the natural environments depends on the efficient isolation of high quality DNA quantitatively from water samples. To verify that the DNA extraction method is highly efficient, a control procedure is needed. Firstly, the DNA content of $O$. marina needs to be measured accurately. Among other methods, flow cytometry, a method commonly used to measure the genome size of different organims is an option [54,55]. Different sample collection, preservation, and DNA extraction methods are compared and the one which gives the closest DNA content with that measured by flow cytometry is chosen for future DNA extraction and the DNA recovery efficiency is calibrated.

18S rDNA is widely used in qPCR because it consists of multiple copies in the genomes of eukaryote and hence a highly sensitive gene marker [165]. The number of 18S rDNA copies in O. marina needs to be measured in order to accurately convert copies per sample to cells per sample. The abundance of $O$. marina in the natural samples can then be quantified using the qPCR method established.

\subsection{O. marina Transcriptomic Study}

While it is still not feasible to completely sequence $O$. marina genome, information on genome structure and function can be gained through gene expression profiling (transcriptomic analysis). Since O. marina is a heterotrophic dinoflagellate, a technical issue associated with the transcriptomic studies is the contamination of the prey cells. The recent discovery of the spliced leader (SL) trans-splicing in dinoflagellate mRNAs offers a unique tool to separate dinoflagellate transcripts from assemblage of different organisms [42,43]. The cDNA libraries of $O$. marina cultured in different conditions can be constructed using a PCR-based method with DinoSL as a forward primer and sequenced using next generation sequencing method. After the functional annotation, the differential expression gene can be retrieved and the interested genes (such as food-related, growth-related genes) can be isolated for future studies.

\section{Acknowledgments}

The study was supported by a Visiting Scholarship of China (to Z.G), “1000-Talent-Plan” award of China at Xiamen University (to S.J.L), Natural Science Foundation of China (grants No. 41176091, No. 41129001 to S.J.L. and No. 41276160 to S.L), NSF “Assembling the Tree of Life” grant EF-0629624 (to S.J.L and collaborators C. Delwiche and W. Coats).

\section{Conflict of Interest}

The authors declare no conflict of interest.

\section{References}

1. Sherr, E.B.; Sherr, B.F. Significance of predation by protists in aquatic microbial food webs. Antonie Van Leeuwenhoek 2002, 81, 293-308. 
2. Roberts, E.C.; Wootton, E.C.; Davidson, K.; Jeong, H.J.; Lowe, C.D.; Montagnes, D.J.S. Feeding in the dinoflagellate Oxyrrhis marina: Linking behaviour with mechanisms. J. Plankton Res. 2011, 33, 603-614.

3. Yang, Z.; Jeong, H.J.; Montagnes, D.J.S. The role of Oxyrrhis marina as a model prey: Current work and future directions. J. Plankton Res. 2011, 33, 665-675.

4. Lowe, C.D.; Martin, L.E.; Montagnes, D.J.; Watts, P.C. A legacy of contrasting spatial genetic structure on either side of the Atlantic-Mediterranean transition zone in a marine protist. Proc. Natl. Acad. Sci. USA 2012, 109, 20998-21003.

5. Jeong, H.J. The ecological roles of heterotrophic dinoflagellates in marine planktonic community. J. Eukaryot. Microbiol. 1999, 46, 190-396.

6. Sherr, E.B.; Sherr, B.F. Heterotrophic dinoflagellates: A significant component of microzooplankton biomass and major grazers of diatoms in the sea. Mar. Ecol. Prog. Ser. 2007, 352, 187-197.

7. Hansen, P.J. Dinophysis-A planktonic dinoflagellate genus which can act both as a prey and a predator of a ciliate. Mar. Ecol. Prog. Ser. 1991, 69, 201-204.

8. Jeong, H.J.; Seong, K.A.; Yoo, Y.D.; Kim, T.H.; Kang, N.S.; Kim, S.; Park, J.Y.; Kim, J.S.; Kim, G.H.; Song, J.Y. Feeding and grazing impact by small marine heterotrophic dinoflagellates on heterotrophic bacteria. J. Eukaryot. Microbiol. 2008, 55, 271-288.

9. Slamovits, C.H.; Keeling, P.J. Plastid-derived genes in the nonphotosynthetic alveolate Oxyrrhis marina. Mol. Biol. Evol. 2008, 25, 1297-1306.

10. Lowe, C.D.; Keeling, P.J.; Martin, L.E.; Slamovits, C.H.; Watts, P.C.; Montagnes, D.J.S. Who is Oxyrrhis marina? Morphological and phylogenetic studies on an unusual dinoflagellate. J. Plankton Res. 2011, 33, 555-567.

11. Watts, P.C.; Martin, L.E.; Kimmance, S.A.; Montagnes, D.J.; Lowe, C.D. The distribution of Oxyrrhis marina: A global disperser or poorly characterized endemic? J. Plankton Res. 2011, 33, 579-589.

12. Tillmann, U. Phagotrophy by a plastidic haptophyte, Prymnesium patelliferurn. Aquat. Microb. Ecol. 1998, 14, 155-160.

13. Tillmann, U. Kill and eat your predator: A winning strategy of the planktonic flagellate Prymnesium parvum. Aquat. Microb. Ecol. 2003, 32, 73-84.

14. Suttle, C.A. Marine viruses-major players in the global ecosystem. Nat. Rev. Microbiol. 2007, 5, 801-812.

15. Mariani, P.; Botte, V.; Ribera d'Alcalà, M. A numerical investigation of the impact of turbulence on the feeding rates of Oithona davisae. J. Mar. Syst. 2008, 70, 273-286.

16. Boakes, D.E.; Codling, E.A.; Thorn, G.J.; Steinke, M. Analysis and modelling of swimming behaviour in Oxyrrhis marina. J. Plankton Res. 2011, 33, 641-649.

17. Lowe, C.D.; Day, A.; Kemp, S.J.; Montagnes, D.J. There are high levels of functional and genetic diversity in Oxyrrhis marina. J. Eukaryot. Microbiol. 2005, 52, 250-257.

18. Montagnes, D.J.S.; Lowe, C.D.; Martin, L.; Watts, P.C.; Downes-Tettmar, N.; Yang, Z.; Roberts, E.C.; Davidson, K. Oxyrrhis marina growth, sex and reproduction. J. Plankton Res. 2011, 33, 615-627.

19. Hartz, A.J.; Sherr, B.F.; Sherr, E.B. Photoresponse in the heterotrophic marine dinoflagellate Oxyrrhis marina. J. Eukaryot. Microbiol. 2011, 58, 171-177. 
20. Montagnes, D.J.S.; Lowe, C.D.; Roberts, E.C.; Breckels, M.N.; Boakes, D.E.; Davidson, K.; Keeling, P.J.; Slamovits, C.H.; Steinke, M.; Yang, Z.; et al. An introduction to the special issue: Oxyrrhis marina, a model organism? J. Plankton Res. 2011, 33, 549-554.

21. Van Meel, L. Etudes hydrobiologiques des eaux saumâtres de belgique: 3. Les étangs galgenweelen à anvers (rive gauche). Bull. K. Belg. Inst. Nat. Wet. 1958, 34, 1-20 (in French).

22. Scheffel, A. Phaeocystis globosa nov. Spec. Nebst einigen betrachtungen Über die phylogenie niederer, insbesondere brauner organismen. In Wissenschaftliche Meeresuntersuchungen (in German); Abteilung Helgoland N. F.: Helgoland, Germany, 1900; Volume 4, pp. 1-29.

23. Conrad, W. Notes protistologiques ix surtroisdinoflagellates de l'eausaumatre. Bull. Mus. Roy. Hist. Nat. Belg. 1939, 15, 1-10 (in French).

24. Kofoid, C.A.; Swezy, O. The Free-Living Unarmored Dinoflagellata; University of California Press: Berkeley, CA, USA, 1921; Volume 5, p. 538.

25. Dodge, J.D.; Hart-Jones, B. Marine Dinoflagellates of the British Isles; HMSO: London, UK, 1982.

26. Cavalier-Smith, T.; Chao, E. Protalveolate phylogeny and systematics and the origins of Sporozoa and dinoflagellates (phylum Myzozoa nom. Nov.). Eur. J. Protistol. 2004, 40, 185-212.

27. Lowe, C.D.; Montagnes, D.J.S.; Martin, L.E.; Watts, P.C. Patterns of genetic diversity in the marine heterotrophic flagellate Oxyrrhis marina (alveolata: Dinophyceae). Protist 2010, 161, 212-221.

28. Lowe, C.D.; Montagnes, D.J.; Martin, L.E.; Watts, P.C. High genetic diversity and fine-scale spatial structure in the marine flagellate Oxyrrhis marina (Dinophyceae) uncovered by microsatellite loci. PLoS One 2010, 5, e15557.

29. Lowe, C.D.; Martin, L.E.; Roberts, E.C.; Watts, P.C.; Wootton, E.C.; Montagnes, D.J.S. Collection, isolation, and culturing strategies for Oxyrrhis marina. J. Plankton Res. 2011, 33, 569-578.

30. Cachon, J.; Cachon, M.; Salvano, P. The nuclear division of Oxyrrhis marina: An example of the role played by the nuclear envelope in chromosome segregation. Arch. Protistenk. 1979, 122, 43-54.

31. Kato, K.H.; Moriyama, A.; Itoh, T.J.; Yamamoto, M.; Horio, T.; Huitorel, P. Dynamic changes in microtubule organization during division of the primitive dinoflagellate Oxyrrhis marina. Biol. Cell 2000, 92, 583-594.

32. Saldarriaga, J.F. Multiple protein phylogenies show that Oxyrrhis marina and Perkinsus marinus are early branches of the dinoflagellate lineage. Int. J. Syst. Evol. Microbiol. 2003, 53, 355-365.

33. Lenaers, G.; Scholin, C.; Bhaud, Y.; Saint-Hilaire, D.; Herzog, M. A molecular phylogeny of dinoflagellate protists (pyrrhophyta) inferred from the sequence of 24S rRNA divergent domains d1 and d8. J. Mol. Evol. 1991, 32, 53-63.

34. Slamovits, C.H.; Saldarriaga, J.F.; Larocque, A.; Keeling, P.J. The highly reduced and fragmented mitochondrial genome of the early-branching dinoflagellate Oxyrrhis marina shares characteristics with both apicomplexan and dinoflagellate mitochondrial genomes. J. Mol. Biol. 2007, 372, 356-368.

35. Leander, B.S.; Keeling, P.J. Early evolutionary history of dinoflagellates and apicomplexans (alveolata) as inferred from HSP90 and actin phylogenies. J. Phycol. 2004, 40, 341-350. 
36. Zhang, H.; Lin, S. mRNA editing and spliced-leader RNA trans-splicing groups Oxyrrhis, Noctiluca, Heterocapsa, and Amphidiniumas basal lineages of dinoflagellates. J. Phycol. 2008, 44, 703-711.

37. Clarke, K.; Pennick, N. The occurrence of body scales in Oxyrrhis marina dujardin. Br. Phycol. J. 1976, 11, 345-348.

38. Clarke, K.; Pennick, N. Flagellar scales in Oxyrrhis marina dujardin. Br. Phycol. J. 1972, 7, 357-360.

39. Cachon, M.; Cosson, J.; Cosson, M.P.; Huitorel, P.; Cachon, J. Ultrastructure of the flagellar apparatus of Oxyrrhis marina. Biol. Cell 1988, 63, 159-168.

40. Roberts, K.R. The flagellar apparatus of Oxyrrhis marina (pyrrophyta). J. Phycol. 1985, 21, 641-655.

41. Roberts, K.; Roberts, J.E. The Flagellar Apparatus and Cytoskeleton of the Dinoflagellates. Protoplasma 1991, 164, 105-122.

42. Kato, K.H.; Moriyama, A.; Huitorel, P.; Cosson, J.; Cachon, M.; Sato, H. Isolation of the major basic nuclear protein and its localization on chromosomes of the dinoflagellate Oxyrrhis marina. Biol. Cell 1997, 89, 43-52.

43. Zhang, H.; Hou, Y.; Miranda, L.; Campbell, D.A.; Sturm, N.R.; Gaasterland, T.; Lin, S. Spliced leader RNA trans-splicing in dinoflagellates. Proc. Natl. Acad. Sci. USA 2007, 104 4618-4623.

44. Zhang, H.; Zhuang, Y.; Gill, J.; Lin, S. Proof that dinoflagellate spliced leader (dinosl) is a useful hook for fishing dinoflagellate transcripts from mixed microbial samples: Symbiodinium kawagutii as a case study. Protist 2013, 164, 510-527.

45. Hall, R.P. Binary Fission in Oxyrrhis marina Dujardin; University of California Press: Berkeley, CA, USA; 1925, Volume 26, pp. 281-324.

46. Triemer, R.E. A unique mitotici variation in the marine dinoflagellate Oxyrrhis marina (pyrrophyta). J. Phycol. 1982, 18, 399-411.

47. Gao, X.; Li, J. Nuclear division in the marine dinoflagellate Oxyrrhis marina. J. Cell Sci. 1986, 85, 161-175.

48. Sano, J.; Kato, K.H. Localization and copy number of the protein-codinggenes actin, $\alpha$-tubulin, and HSP90 in the nucleus of a primitive dinoflagellate, Oxyrrhis marina. Zool. Sci. 2009, 26, 745-753.

49. Slamovits, C.H.; Keeling, P.J. Contributions of Oxyrrhis marina to molecular biology, genomics and organelle evolution of dinoflagellates. J. Plankton Res. 2011, 33, 591-602.

50. Coats, D.W. Dinoflagellate life-cycle complexities. J. Phycol. 2002, 38, 417-419.

51. Santos, S.R.; Coffroth, M.A. Molecular genetic evidence that dinoflagellates belonging to the genus Symbiodinium freudenthal are haploid. Biol. Bull. 2003, 204, 10-20.

52. Hausmann, K.; Hülsmann, N.; Radek, R. Protistology; E. Schweizerbart'sche Verlagsbuchhandlung: Berlin, Germany, 2003.

53. Hackett, J.D.; Anderson, D.M.; Erdner, D.L.; Bhattacharya, D. Dinoflagellates: A remarkable evolutionary experiment. Am. J. Bot. 2004, 91, 1523-1534. 
54. Veldhuis, M.J.W.; Cucci, T.L.; Sieracki, M.E. Cellular DNA content of marine phytoplankton using two new fluorochromes: Taxonomic and ecological implications. J. Phycol. 1997, 33, 527-541.

55. LaJeunesse, T.C.; Lambert, G.; Anderson, R.A.; Coffroth, M.A.; Galbraith, D.W. Symbiodinium (Pyrrhophyta) genome sizes (DNA content) are smallest among dinoflagellates. J. Phycol. 2005, 41, 880-886.

56. Le, Q.; Markovic, P.; Hastings, J.; Jovine, R.; Morse, D. Structure and organization of the peridinin-chlorophyll $a$-binding protein gene in Gonyaulax polyedra. Mol. Gen. Genet. 1997, 255, 595-604.

57. Reichman, J.R.; Wilcox, T.P.; Vize, P.D. PCP gene family in Symbiodinium from Hippopus hippopus: Low levels of concerted evolution, isoform diversity, and spectral tuning of chromophores. Mol. Biol. Evol. 2003, 20, 2143-2154.

58. Bachvaroff, T.R.; Place, A.R. From stop to start: Tandem gene arrangement, copy number and trans-splicing sites in the dinoflagellate Amphidinium carterae. PLoS One 2008, 3, e2929.

59. Galluzzi, L.; Bertozzini, E.; Penna, A.; Perini, F.; Garcés, E.; Magnani, M. Analysis of rRNA gene content in the mediterranean dinoflagellate Alexandrium catenella and Alexandrium taylori: Implications for the quantitative real-time PCR-based monitoring methods. J. Appl. Phycol. 2009, 22, 1-9.

60. Erdner, D.L.; Percy, L.; Keafer, B.; Lewis, J.; Anderson, D.M. A quantitative real-time PCR assay for the identification and enumeration of Alexandrium cysts in marine sediments. Deep Sea Res. Part II Top. Stud. Oceanogr. 2010, 57, 279-287.

61. Zhang, H.; Lin, S. Complex gene structure of the form II Rubisco in the dinoflagellate Prorocentrum minimum (Dinophyceae). J. Phycol. 2003, 39, 1160-1171.

62. Li, L.; Hastings, J.W. The structure and organization of the luciferase gene in the photosynthetic dinoflagellate Gonyaulax polyedra. Plant Mol. Biol. 1998, 36, 275-284.

63. Zhang, H.; Hou, Y.; Lin, S. Isolation and characterization of proliferating cell nuclear antigen from the dinoflagellate Pfiesteria piscicida. J. Eukaryot. Microbiol. 2006, 53, 142-150.

64. Zhang, H.; Dungan, C.F.; Lin, S. Introns, alternative splicing, spliced leader trans-splicing and differential expression of pcna and cyclin in Perkinsus marinus. Protist 2011, 162, 154-167.

65. Beauchemin, M.; Roy, S.; Daoust, P.; Dagenais-Bellefeuille, S.; Bertomeu, T.; Letourneau, L.; Lang, B.F.; Morse, D. Dinoflagellate tandem array gene transcripts are highly conserved and not polycistronic. Proc. Natl. Acad. Sci. USA 2012, 109, 15793-15798.

66. Lowe, C.D.; Mello, L.V.; Samatar, N.; Martin, L.E.; Montagnes, D.J.S.; Watts, P.C. The transcriptome of the novel dinoflagellate Oxyrrhis marina (alveolata: Dinophyceae): Response to salinity examined by 454 sequencing. BMC Genomics 2011, doi:10.1186/1471-2164-12-519.

67. Waller, R.F.; Slamovits, C.H.; Keeling, P.J. Lateral gene transfer of a multigene region from cyanobacteria to dinoflagellates resulting in a novel plastid-targeted fusion protein. Mol. Biol. Evol. 2006, 23, 1437-1443.

68. Delwiche, C.F.; Palmer, J.D. Rampant horizontal transfer and duplication of rubisco genes in eubacteria and plastids. Mol. Biol. Evol. 1996, 13, 873-882.

69. Morse, D.; Salois, P.; Markovic, P.; Hastings, J.W. A nuclear-encoded form II rubisco in dinoflagellates. Science 1995, 268, 1622-1624. 
70. Lin, S.; Zhang, H.; Spencer, D.F.; Norman, J.E.; Gray, M.W. Widespread and extensive editing of mitochondrial mRNAs in dinoflagellates. J. Mol. Biol. 2002, 320, 727-739.

71. Jackson, C.J.; Norman, J.E.; Schnare, M.N.; Gray, M.W.; Keeling, P.J.; Waller, R.F. Broad genomic and transcriptional analysis reveals a highly derived genome in dinoflagellate mitochondria. BMC Biol. 2007, doi:10.1186/1741-7007-5-41.

72. Zhang, H.; Lin, S. Mitochondrial cytochrome b mRNA editing in dinoflagellates: Possible ecological and evolutionary associations? J. Eukaryot. Microbiol. 2005, 52, 538-545.

73. Zhang, H.; Bhattacharya, D.; Lin, S. A three-gene dinoflagellate phylogeny suggests monophyly of prorocentrales and a basal position for Amphidinium and Heterocapsa. J. Mol. Evol. 2007, 65, 463-474.

74. Sanchez-Puerta, M.V.; Lippmeier, J.C.; Apt, K.E.; Delwiche, C.F. Plastid genes in a non-photosynthetic dinoflagellate. Protist 2007, 158, 105-117.

75. Lin, S.; Zhang, H.; Gray, M.W. RNA Editing in Dinoflagellates and Its Implications for the Evolutionary History of the Editing Machinery. In RNA and DNA Editing: Molecular Mechanisms and Their Integration into Biological Systems; Smith, H.C., Ed.; John Wiley \& Sons, Inc.: Hoboken, NJ, USA, 2008; pp. 280-309.

76. Jackson, C.; Gornik, S.; Waller, R. The mitochondrial genome and transcriptome of the basal dinoflagellate Hematodinium sp.: Character evolution within the highly derived mitochondrial genomes of dinoflagellates. Genome Biol. Evol. 2012, 4, 59-72.

77. Williamson, D.H.; Gardner, M.J.; Preiser, P.; Moore, D.J.; Rangachari, K.; Wilson, R.J. The evolutionary origin of the $35 \mathrm{~kb}$ circular DNA of Plasmodium falciparum: New evidence supports a possible rhodophyte ancestry. Mol. Gen. Genet. 1994, 243, 249-252.

78. Denny, P.W.; Preiser, P.R.; Rangachari, K.; Roberts, K.; Roy, A.; Whyte, A.; Strath, M.; Moore, D.J.; Moore, P.W.; Williamson, D.H. Complete gene map of the plastid-like DNA of the malaria parasite Plasmodium falciparum. J. Mol. Biol. 1996, 261, 155-172.

79. Huang, J.; Mullapudi, N.; Sicheritz-Ponten, T.; Kissinger, J.C. A first glimpse into the pattern and scale of gene transfer in the apicomplexa. Int. J. Parasitol. 2004, 34, 265-274.

80. Archibald, J.M. Plastid evolution: Remnant algal genes in ciliates. Curr. Biol. 2008, 18, R663-R665.

81. Reyes-Prieto, A.; Moustafa, A.; Bhattacharya, D. Multiple genes of apparent algal origin suggest ciliates may once have been photosynthetic. Curr. Biol. 2008, 18, 956-962.

82. Stelter, K.; El-Sayed, N.M.; Seeber, F. The expression of a plant-type ferredoxin redox system provides molecular evidence for a plastid in the early dinoflagellate Perkinsus marinus. Protist 2007, 158, 119-130.

83. Matsuzaki, M.; Kuroiwa, H.; Kuroiwa, T.; Kita, K.; Nozaki, H. A cryptic algal group unveiled: A plastid biosynthesis pathway in the oyster parasite Perkinsus marinus. Mol. Biol. Evol. 2008, 25, 1167-1179.

84. Sheiner, L.; Vaidya, A.B.; McFadden, G.I. The metabolic roles of the endosymbiotic organelles of Toxoplasma and Plasmodium spp. Curr. Opin. Microbiol. 2013, 16, 452-458.

85. Cavalier-smith, T. Principles of protein and lipid targeting in secondary symbiogenesis: Euglenoid, dinoflagellate, and sporozoan plastid origins and the eukaryote family tree 1,2. J. Eukaryot. Microbiol. 1999, 46, 347-366. 
86. Patron, N.J.; Rogers, M.B.; Keeling, P.J. Gene replacement of fructose-1,6-bisphosphate aldolase supports the hypothesis of a single photosynthetic ancestor of chromalveolates. Eukaryot. Cell 2004, 3, 1169-1175.

87. Keeling, P.J. Chromalveolates and the evolution of plastids by secondary endosymbiosis. J. Eukaryot. Microbiol. 2009, 56, 1-8.

88. Goldman, J.C.; Dennett, M.R.; Gordin, H. Dynamics of herbivorous grazing by the heterotrophic dinoflagellate Oxyrrhis marina. J. Plankton Res. 1989, 11, 391-407.

89. Hansen, F.C.; Witte, H.J.; Passarge, J. Grazing in the heterotrophic dinoflagellate Oxyrrhis marina: Size selectivity and preference for calcified Emiliania huxleyi cells. Aquat. Microb. Ecol. 1996, 10, 307-313.

90. Jeong, H.J.; Kang, H.; Shim, J.H.; Park, J.K.; Kim, J.S.; Song, J.Y.; Choi, H.J. Interactions among the toxic dinoflagellate Amphidinium carterae, the heterotrophic dinoflagellate Oxyrrhis marina, and the calanoid copepods acartia spp. Mar. Ecol. Prog. Ser. 2001, 218, 77-86.

91. Jeong, H.J.; Kim, J.S.; Yoo, Y.D.; Kim, S.T.; Kim, T.H.; Park, M.G.; Lee, C.H.; Seong, K.A.; Rang, N.S.; Shim, J.H. Feeding by the heterotrophic dinoflagellate Oxyrrhis marina on the red-tide raphidophyte Heterosigma akashiwo: A potential biological method to control red tides using mass-cultured grazers. J. Eukaryot. Microbiol. 2003, 50, 274-282.

92. Hammer, A.; Grüttner, C.; Schumann, R. The effect of electrostatic charge of food particles on capture efficiency by Oxyrrhis marina dujardin (dinoflagellate). Protist 1999, 150, 375-382.

93. Hammer, A.; Gruttner, C.; Schumann, R. New biocompatible tracer particles: Use for estimation of microzooplankton grazing, digestion, and growth rates. Aquat. Microb. Ecol. 2001, 24, 153-161.

94. Wootton, E.C.; Zubkov, M.V.; Jones, D.H.; Jones, R.H.; Martel, C.M.; Thornton, C.A.; Roberts, E.C. Biochemical prey recognition by planktonic protozoa. Environ. Microbiol. 2007, 9, 216-222.

95. Sieburth, J.M. Acrylic acid, an "antibiotic" principle in phaeocystis blooms in antarctic waters. Science 1960, 132, 676-677.

96. Barlow, R.; Burkill, P.; Mantoura, R. Grazing and degradation of algal pigments by marine protozoan Oxyrrhis marina. J. Exp. Mar. Biol. Ecol. 1988, 119, 119-129.

97. Flynn, K.J.; Davidson, K.; Cunningham, A. Prey selection and rejection by a microflagellate: Implications for the study and operation of microbial food webs. J. Exp. Mar. Biol. Ecol. 1996, 196, 357-372.

98. Monger, B.C.; Landry, M.R.; Brown, S.L. Feeding selection of heterotrophic marine nanoflagellates based on the surface hydrophobicity of their picoplankton prey. Limnol. Oceanogr. 1999, 44, 1917-1927.

99. John, E.; Davidson, K. Prey selectivity and the influence of prey carbon: Nitrogen ratio on microflagellate grazing. J. Exp. Mar. Biol. Ecol. 2001, 260, 93-111.

100. Matz, C.; Jurgens, K. Effects of hydrophobic and electrostatic cell surface properties of bacteria on feeding rates of heterotrophic nanoflagellates. Appl. Environ. Microbiol. 2001, 67, 814-820.

101. Matz, C.; Jürgens, K. High motility reduces grazing mortality of planktonic bacteria. Appl. Environ. Microbiol. 2005, 71, 921-929. 
102. Matz, C.; Boenigk, J.; Arndt, H.; Jürgens, K. Role of bacterial phenotypic traits in selective feeding of the heterotrophic nanoflagellate Spumella sp. Aquat. Microb. Ecol. 2002, 27, 137-148.

103. Wolfe, G.V.; Steinke, M.; Kirst, G.O. Grazing-activated chemical defence in a unicellular marine alga. Nature 1997, 387, 894-897.

104. Evans, C.; Wilson, W.H. Preferential grazing of Oxyrrhis marina on virus-infected Emiliania huxleyi. Limnol. Oceanogr. 2008, 53, 2035-2040.

105. Droop, M.R. Nutritional investigation of phagotrophic protozoa under axenic conditions. Helgoländer Wiss. Meeresunters. 1970, 20, 272-277.

106. Droop, M.R. Water-soluble factors in the nutrition of Oxyrrhis marina. J. Mar. Biol. Assoc. UK 1959, 38, 605-620.

107. Droop, M.R.; Pennock, J.F. Terpenoid quinones and steroids in the nutrition of Oxyrrhis marina. J. Mar. Biol. Assoc. UK 1971, 51, 455-470.

108. Öpik, H.; Flynn, K. The digestive process of the dinoflagellate, Oxyrrhis marina dujardin, feeding on the chlorophyte, Dunaliella primolecta butcher: A combined study of ultrastructure and free amino acids. New Phytol. 1989, 113, 143-151.

109. Mast, S.; Stahler, N. The relation between luminous intensity, adaptation to light, and rate of locomotion in Amoeba proteus (leidy). Biol. Bull. 1937, 73, 126-133.

110. Podesta, A.; Marangoni, R.; Vilani, C.; Colombetti, G. A rhodopsin-like molecule on the plasma membrane of Fabrea salina. J. Eukaryot. Microbiol. 1994, 41, 565-569.

111. Seibach, M.; Hader, D.P.; Kuhlmann, H.W. Phototaxis in Chlamydodon mnemosyne: Determination of the illuminance-response curve and the action spectrum. J. Photochem. Photobiol. B Biol. 1999, 49, 35-40.

112. Cadetti, L.; Marroni, F.; Marangoni, R.; Kuhlmann, H.-W.; Gioffre, D.; Colombetti, G. Phototaxis in the ciliated protozoan Ophryoglena flava: Dose-effect curves and action spectrum determination. J. Photochem. Photobiol. B Biol. 2000, 57, 41-50.

113. Saranak, J.; Foster, K.W. Photoreceptor for curling behavior in Peranema trichophorum and evolution of eukaryotic rhodopsins. Eukaryot. Cell 2005, 4, 1605-1612.

114. Lobban, C.S.; Hallam, S.J.; Mukherjee, P.; Petrich, J.W. Photophysics and multifunctionality of hypericin-like pigments in heterotrich ciliates: A phylogenetic perspective. Photochem. Photobiol. 2007, 83, 1074-1094.

115. Fabczak, H.; Sobierajska, K.; Fabczak, S. A rhodopsin immunoanalog in the related photosensitive protozoans Blepharisma japonicum and Stentor coeruleus. Photochem. Photobiol. Sci. 2008, 7, 1041-1045.

116. Jakobsen, H.H.; Strom, S.L. Circadian cycles in growth and feeding rates of heterotrophic protist plankton. Limnol. Oceanogr. 2004, 49, 1915-1922.

117. Strom, S.L. Light-aided digestion, grazing and growth in herbivorous protists. Aquat. Microb. Ecol. 2001, 23, 253-261.

118. Skovgaard, A. A phagotrophically derivable growth factor in the plastic dinoflagellates Gyrodinium resplendens. J. Phycol. 2000, 36, 1069-1078.

119. Jakobsen, H.H.; Hansen, P.J.; Larsen, J. Growth and grazing responses of two chloroplast-retaining dinoflagellates: Effect of irradiance and prey species. Mar. Ecol. Prog. Ser. 2000, 201, 121-128. 
120. Li, A.; Stoecker, D.K.; Adolf, J.E. Feeding, pigmentation, photosynthesis and growth of the mixotrophic dinoflagellate Gyrodinium galatheanum. Aquat. Microb. Ecol. 1999, 19, 163-176.

121. Moran, M.A.; Zepp, R.G. Role of photoreactions in the formation of biologically labile compounds from dissolved organic matter. Limnol. Oceanogr. 1997, 42, 1307-1316.

122. Klein, B.; Gieskes, W.W.; Krray, G.G. Digestion of chlorophylls and carotenoids by the marine protozoan Oxyrrhis marina studied by HPLC analysis of algal pigments. J. Plankton Res. 1986, 8, 827-836.

123. Béja, O.; Aravind, L.; Koonin, E.V.; Suzuki, M.T.; Hadd, A.; Nguyen, L.P.; Jovanovich, S.B.; Gates, C.M.; Feldman, R.A.; Spudich, J.L. Bacterial rhodopsin: Evidence for a new type of phototrophy in the sea. Science 2000, 289, 1902-1906.

124. Béja, O.; Spudich, E.N.; Spudich, J.L.; Leclerc, M.; DeLong, E.F. Proteorhodopsin phototrophy in the ocean. Nature 2001, 411, 786-789.

125. Lin, S.; Zhang, H.; Zhuang, Y.; Tran, B.; Gill, J. Spliced leader-based metatranscriptomic analyses lead to recognition of hidden genomic features in dinoflagellates. Proc. Natl. Acad. Sci. USA 2010, 107, 20033-20038.

126. Slamovits, C.H.; Okamoto, N.; Burri, L.; James, E.R.; Keeling, P.J. A bacterial proteorhodopsin proton pump in marine eukaryotes. Nat. Commun. 2011, doi:10.1038/ncomms1188.

127. Kent, W.S. A Manual of the Infusoria: Including a Description of All Known Flagellate, Ciliate, and Tentaculiferous Protozoa, British and Foreign, and an Account of the Organization and the Affinities of the Sponges; D. Bogue: London, UK, 1880.

128. Senn, G. Oxyrrhis, Nephroselmis und einige Euflagellaten, nebst Bemerkungen uber deren System; Wilhelm Engelmann: Leipzig, Germany, 1911; pp. 604-672.

129. Cosson, J.; Cachon, M.; Cachon, J.; Cosson, M.-P. Swimming behaviour of the unicellular biflagellate Oxyrrhis marina: In vivo and in vitro movement of the two flagella. Biol. Cell 1988, 63, 117-126.

130. Bartumeus, F.; Peters, F.; Pueyo, S.; Marrasé, C.; Catalan, J. Helical lévy walks: Adjusting searching statistics to resource availability in microzooplankton. Proc. Natl. Acad. Sci. USA 2003, 100, 12771-12775.

131. Crenshaw, H.C. A new look at locomotion in microorganisms: Rotating and translating. Am. Zool. 1996, 36, 608-618.

132. Tarran, G.A. Aspects of Grazing Behaviour of the Marine Dinoflagellate Oxyrrhis marina, Dujardin; University of Southampton: Southampton, UK, 1991.

133. Menden-Deuer, S.; Grünbaum, D. Individual foraging behaviors and population distributions of a planktonic predator aggregating to phytoplankton thin layers. Limnol. Oceanogr. 2006, 51, 109-116.

134. Grünbaum, D. Predicting availability to consumers of spatially and temporally variable resources. Hydrobiologia 2002, 480, 175-191.

135. Hartz, A.J.; Sherr, B.F.; Sherr, E.B. Using inhibitors to investigate the involvement of cell signaling in predation by marine phagotrophic protists. J. Eukaryot. Microbiol. 2008, 55, $18-21$.

136. Fenchel, T. Ecology of Protozoa: The Biology of Free-Living Phagotrophic Protists; Springer-Verlag: Madison, WI, USA, 1987. 
137. Höhfeld, I.; Melkonian, M. Lifting the curtain? The microtubular cytoskeleton of Oxyrrhis marina (Dinophyceae) and its rearrangement during phagocytosis. Protist 1998, 149, 75-88.

138. Barker, H.A. The culture and physiology of the marine dinoflagellates. Arch. Microbiol. 1935, 6, 157-181.

139. Flynn, K.J.; Davidson, K. Predator-prey interactions between Isochrysis galbana and Oxyrrhis marina. II. Release of non-protein amines and faeces during predation of isochrysis. J. Plankton Res. 1993, 15, 893-905.

140. Bretler, W. Continuous breeding of marine pelagic copepods in the presence of heterotrophic dinoflagellates. Mar. Ecol. Prog. Ser. 1980, 2, 229-233.

141. Hansen, B.; Bjørnsen, P.K.; Hansen, P.J. The size ratio between planktonic predators and their prey. Limnol. Oceanogr. 1994, 39, 395-403.

142. Breteler, W.K.; Schogt, N.; Baas, M.; Schouten, S.; Kraay, G. Trophic upgrading of food quality by protozoans enhancing copepod growth: Role of essential lipids. Mar. Biol. 1999, 135, 191-198.

143. Scott, J. Further nutritional studies on the marine rotifer encentrum linnhei. Rotifer Symp. IV 1987, 42, 303-306.

144. Pfiester, L.A.; Anderson, D.M. Dinoflagellate reproduction. In The Biology of Dinoflagellates; Taylor, F.J.R.; Ed.; Blackwell Scientific Publications: Hoboken, NJ, USA, 1987, Volume 21, pp. 611-648.

145. Whiteley, A.; Burkill, P.; Sleigh, M. Rapid method for cell cycle analysis in a predatory marine dinoflagellate. Cytometry 1993, 14, 909-915.

146. Lin, S.; Mulholland, M.R.; Zhang, H.; Feinstein, T.N.; Jochem, F.J.; Carpenter, E.J. Intense grazing and prey-dependent growth of Pfiesteria piscicida (Dinophyceae). J. Phycol. 2004, 40, 1062-1073.

147. Begun, A.; Orlova, T.Y.; Selina, M. A "bloom” in the water of Amursky bay (sea of Japan) caused by the dinoflagellate Oxyrrhis marina dujardin, 1841. Russ. J. Mar. Biol. 2004, 30, 51-55.

148. Kimmance, S.A.; Atkinson, D.; Montagnes, D.J. Do temperature-food interactions matter? Responses of production and its components in the model heterotrophic flagellate Oxyrrhis marina. Aquat. Microb. Ecol. 2006, 42, 63-73.

149. Jonsson, P.R. Tidal rhythm of cyst formation in the rock pool ciliate Strombidium oculatum gruber (ciliophora, oligotrichida): A description of the functional biology and an analysis of the tidal synchronization of encystment. J. Exp. Mar. Biol. Ecol. 1994, 175, 77-103.

150. Anderson, D.M.; Wall, D. Potential importance of benthic cysts of Gonyaulax tamarensis and G. excavata in initiating toxic dinoflagellate blooms. J. Phycol. 1978, 14, 224-234.

151. Matthiessen, J., de Vernal, A.; Head, M.; Okolodkov, Y.; Harland, R. Modern organic-walled dinoflagellate cysts in Arctic marine environments and their (paleo-) environmental significance. Paläontologische Zeitschrift 2005, 79, 3-51.

152. Vink, A.; Zonneveld, K.A.F.; Willems, H. Organic-walled dinoflagellate cysts in western equatorial Atlantic surface sediments: Distribution and their relation to environment. Rev. Palaeobot. Palynol. 2000, 112, 247-286.

153. Wall, D. Biological problems concerning fossilizable dinoflagellates. Geosci. Man 1971, 2, 1-15.

154. Droop, M.R. A note on some physical conditions for cultivating Oxyrrhis marina. J. Mar. Biol. Assoc. UK 1959, 38, 599-604. 
155. Havskum, H. Effects of small-scale turbulence on interactions between the heterotrophic dinoflagellate Oxyrrhis marina and its prey, Isochrysis sp. Ophelia 2003, 57, 125-135.

156. Pedersen, M.F.; Hansen, P.J. Effects of high $\mathrm{pH}$ on the growth and survival of six marine heterotrophic protists. Mar. Ecol. Prog. Ser. 2003, 260, 33-41.

157. Peters, F.; Marrasé, C. Effects of turbulence on plankton: An overview of experimental evidence and some theoretical considerations. Mar. Ecol. Prog. Ser. 2000, 205, 291-306.

158. Davidson, K.; Sayegh, F.; Montagnes, D.J.S. Oxyrrhis marina-based models as a tool to interpret protozoan population dynamics. J. Plankton Res. 2011, 33, 651-663.

159. Johnson, M. Physical control of plankton population abundance and dynamics in intertidal rock pools. Hydrobiologia 2000, 440, 145-152.

160. Hansson, H.G. South scandinavian marine protoctista. Provisional Check-list Compiled at the Tjarno Marine Biological Laboratory. Available online: http:/www.yumpu.com/it/document/view/ 5925990/south-scandinavian-marine-protoctista-protoctista-tmbl (accessed on 10 October 2013).

161. Orlova, T.Y.; Stonik, I.; Shevchenko, O. Flora of planktonic microalgae of Amursky bay, sea of Japan. Russ. J. Mar. Biol. 2009, 35, 60-78.

162. Quevedo, M.; Anado, R. Spring microzooplankton composition, biomass and potential grazing in the central cantabrian coast (southern bay of biscay). Oceanol. Acta 2000, 23, 297-310.

163. Johnson, M.D.; Rome, M.; Stoecker, D.K. Microzooplankton grazing on Prorocentrum minimum and Karlodinium micrum in chesapeake bay. Limnol. Oceanogr. 2003, 48, 238-248.

164. Galluzzi, L.; Penna, A.; Bertozzini, E.; Vila, M.; Garces, E.; Magnani, M. Development of a real-time PCR assay for rapid detection and quantification of Alexandrium minutum (a dinoflagellate). Appl. Environ. Microbiol. 2004, 70, 1199-1206.

165. Zhang, H.; Lin, S. Development of a cob-18S rRNA gene real-time PCR assay for quantifying Pfiesteria shumwayae in the natural environment. Appl. Environ. Microbiol. 2005, 71, 7053-7063.

166. Touzet, N.; Keady, E.; Raine, R.; Maher, M. Evaluation of taxa-specific real-time PCR, whole-cell fish and morphotaxonomy analyses for the detection and quantification of the toxic microalgae Alexandrium minutum (Dinophyceae), global clade ribotype. FEMS Microbiol. Ecol. 2009, 67, 329-341.

167. Dyhrman, S.T.; Erdner, D.; Du, J.L.; Galac, M.; Anderson, D.M. Molecular quantification of toxic Alexandrium fundyense in the gulf of maine using real-time PCR. Harmful Algae 2006, 5, 242-250.

168. Hosoi-Tanabe, S.; Sako, Y. Species-specific detection and quantification of toxic marine dinoflagellates Alexandrium tamarense and A. catenella by real-time PCR assay. Mar. Biotechnol. 2005, 7, 506-514.

169. Wang, L.; Zhuang, Y.; Zhang, H.; Lin, X.; Lin, S. DNA barcoding species in Alexandrium tamarense complex using ITS and proposing designation of five species. Harmful Algae 2013, in press.

170. Yuan, J.; Mi, T.; Zhen, Y.; Yu, Z. Development of a rapid detection and quantification method of Karenia mikimotoi by real-time quantitative PCR. Harmful Algae 2012, 17, 83-91.

171. Zhang, H.; Litaker, W.; Vandersea, M.W.; Tester, P.; Lin, S. Geographic distribution of Karlodinium veneficum in the US east coast as detected by ITS-ferredoxin real-time PCR assay. J. Plankton Res. 2008, 30, 905-922. 
172. Bowers, H.A.; Tengs, T.; Glasgow, H.B.; Burkholder, J.M.; Rublee, P.A.; Oldach, D.W. Development of real-time PCR assays for rapid detection of Pfiesteria piscicida and related dinoflagellates. Appl. Environ. Microbiol. 2000, 66, 4641-4648.

173. Mieog, J.C.; van Oppen, M.J.; Berkelmans, R.; Stam, W.T.; Olsen, J.L. Quantification of algal endosymbionts (Symbiodinium) in coral tissue using real-time PCR. Mol. Ecol. Resour. 2009, 9, 74-82.

(C) 2013 by the authors; licensee MDPI, Basel, Switzerland. This article is an open access article distributed under the terms and conditions of the Creative Commons Attribution license (http://creativecommons.org/licenses/by/3.0/). 